\title{
Protist herbivory in the Oregon upwelling system
}

\author{
Susanne Neuer *, Timothy J. Cowles \\ College of Oceanic and Atmospheric Sciences, Oregon State University, Corvallis, Oregon 97331, USA
}

\begin{abstract}
We investigated the role of phagotrophic protists in the Oregon upwelling system over a 2 yr period by determining protist abundance, and by measuring grazing and phytoplankton growth rates with the seawater-dilution method. Off Oregon (USA), upwelling occurs predominantly during the summer months as episodic upwelling events which give rise to phytoplankton blooms. Abundance of phagotrophic protists, grouped into ciliates (mostly choreotrich forms), thecate and gymnodinoid dinoflagellates and nonpigmented nanoflagellates, was lowest in freshly upwelled water $\left(3 \mu \mathrm{g} \mathrm{C}^{-1}\right.$ ) and highest during the late stages of the phytoplankton blooms $\left(61 \mu \mathrm{g} \mathrm{Cl}^{-1}\right)$. Overall rates of herbivory ranged from 0 to $0.6 \mathrm{~d}^{-1}$ during the upwelling season which represented 0 to $120 \%$ of the phytoplankton production. Highest phytoplankton growth rates were measured during bloom periods in the upwelling season $\left(0.67\right.$ to $\left.1.58 \mathrm{~d}^{-1}\right)$ when phytoplankton biomass was highest $\left(10.7\right.$ to $\left.55.3 \mu \mathrm{g} \mathrm{chl} \mathrm{a}^{-1}\right)$. During bloom periods, phagotrophic protists utilized 16 to $52 \%$ of phytoplankton production, or 612 to $1413 \mu \mathrm{C}^{-1} \mathrm{~d}^{-1}$. Gymnodinoid dinoflagellates were most abundant during the upwelling season, often exceeding the biovolume of choreotrich ciliates and of thecate dinoflagellates. Rates of herbivory were closely linked to the abundance of this group of dinoflagellates. The abundance of large-celled

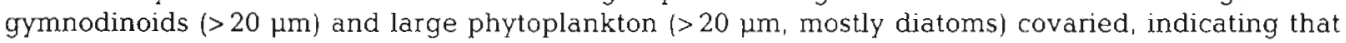
the bloom-forming diatoms were being utilized as a food source. Thus, the microbial food web is an integral part of the trophic interactions in coastal upwelling systems including large phytoplankton cells as prey of protist grazers.
\end{abstract}

KEY WORDS: Microzooplankton - Upwelling · Phagotrophic protists · Microbial food web · Herbivory

\section{INTRODUCTION}

Over the past decade, numerous studies have advanced our understanding of the diverse functional roles of protists and their trophic interactions (e.g. Azam et al. 1983, Ducklow 1983, Wheeler \& Kirchman 1986, Burkill et al. 1987, Sanders \& Porter 1988, Sherr \& Sherr 1988, 1991, Stoecker et al. 1988, Caron \& Goldman 1990). Recent studies have also shown the importance of phagotrophic protists in regions with a high input of new nutrients (Dugdale \& Goering 1967) where trophic interactions were conceptualized by the diatom-mesozooplankton-fish food chain. For example, the classic grazing food chain of the Antarctic has been revised after protozoa were found to graze a large fraction of primary and bacterial production (see Garrison 1991 for review). Recent studies conducted

- Present address: Dept of Geosciences, FB 5, University of Bremen, Klagenfurter Straße, D-28359 Bremen, Germany during the North Atlantic spring bloom also found phagotrophic protists to efficiently utilize phytoplankton production (Burkill et al. 1993, Verity et al. 1993b). On the other hand, our understanding of coastal upwelling systems is still strongly influenced by Ryther's (1969) classical study in which he assigned the fewest trophic levels and highest trophic efficiency to upwelling regions when estimating fish production in open ocean, coastal and upwelling environments.

The flux of organic matter out of the euphotic zone is determined by the community structure of the food web and the proportion of the primary production being grazed by protozooplankton herbivores (Eppley \& Peterson 1979, Welschmeyer \& Lorenzen 1985, Michaels \& Silver 1988). Because of the high productivity of upwelling regions and their importance for carbon flux from continental shelves to slopes (Walsh et al. 1981), more knowledge on the magnitude and variability of protist herbivory in upwelling regions is needed. To date, no systematic study of the importance 
of protist grazing in upwelling regions is available. We know from studies that have estimated protozooplankton abundance in upwelling regions along the west coast of the Americas (off Washington, USA: Chester 1978, Landry \& Hassett 1982, Landry \& Lorenzen 1989; off California, USA: Beers \& Stewart 1967. 1970, Heinbokel 1978, Kimor 1981; and off Peru: Beers et al. 1971, Sorokin 1978, 1980) that phagotrophic protists can be an important component of the plankton community in these regions. In addition, Landry \& Hassett (1982) found microzooplankton (zooplankton $<200 \mu \mathrm{m}$, mostly phagotrophic protists) grazing to be of considerable importance on the Washington shelf.

Upwelling off the Oregon coast occurs primarily during the summer upwelling season as 'upwelling events' when the along-shore wind stress is strong enough to cause significant offshore transport of surface water (Smith 1968, Huyer 1976). During each upwelling event, deep water replete with new nutrients is advected offshore and stabilizes due to solar heating, providing phytoplankton with ideal growth conditions (Barber \& Smith 1981, Small \& Menzies 1981). As many as 5 major upwelling events can occur during an upwelling season (Huyer 1976), each giving rise to phytoplankton blooms that have been compared to spring blooms due to their large biomass, primary production and export of organic material (Barber \& Smith 1981).

This 2 yr study is a systematic investigation of protist abundance and herbivory in the upwelling region of Oregon as part of a group investigation studying the Oregon upwelling system (Neuer 1992, Fessenden \& Cowles 1994, M.-L. Dickson \& P. A. Wheeler unpubl.). We combined data on protist community structure with grazing and phytoplankton growth rates during upwelling and non-upwelling seasons to quantify the grazing impact of the protists on the primary production, as well as determine the importance of different taxonomic groups of grazers.

\section{METHODS}

Dilution technique. We determined grazing and phytoplankton growth rates by applying the dilution technique (Landry \& Hassett 1982, Landry et al. 1984). By diluting planktonic populations in the seawater successively with organism-free seawater from the same site, it is possible to separate autotrophic and heterotrophic processes and determine both phytoplankton growth and zooplankton grazing rates in the same experiment. The apparent phytoplankton growth rate $k\left(\mathrm{~d}^{-1}\right)$ in each dilution during the incubation period is plotted versus dilution factor (proportion of initial undiluted chlorophyll). The slope of the linear regression is the grazing rate, $g\left(\mathrm{~d}^{-1}\right)$ and the intercept with the $y$ axis at a hypothetical maximal dilution is the instantaneous phytoplankton growth rate, $\mu\left(\mathrm{d}^{-1}\right)$ (for examples see Fig. 5). Four major assumptions are implicit in the method: (1) phytoplankton growth and grazing can be expressed by an exponential function, (2) phytoplankton growth rate is constant regardless of the amount of dilution, (3) grazing is linear within the range of biomass in the different dilutions, i.e. clearance rates are unaffected by the dilutions, and (4) microzooplankton density does not change during the incubation period. The second assumption is likely violated by nutrient limitation in 2 ways. As grazing pressure is reduced with increasing dilution, the supply of regenerated nutrients is also diminished (Neuer \& Franks 1993). If the growth of the phytoplankton community is supplied by regenerated nutrients and ambient nutrient levels are low, phytoplankton growth in the highest dilutions could be limited. Subsequently, $\mu$ and $g$ would be underestimated. If, however, the phytoplankton community as a whole is nutrient limited, the dilutions that contain a higher fraction of undiluted seawater could be limited more than the dilutions that contain a lower phytoplankton standing stock. In this case, phytoplankton growth and grazing rates would be overestimated (see also Gifford 1988). We addressed the specific case of ammonium limitation by adding ammonium to a replicate set of dilutions. Ammonium is the primary regenerated nitrogen source excreted by protozooplankton (Caron \& Goldman 1990) and is often the preferred nitrogen source for phytoplankton even if nitrate is available (Wheeler \& Kokkinakis 1990, Price et al. 1991).

Sampling and experimental design. Dilution experiments were carried out monthly to bimonthly with water collected during upwelling and non-upwelling seasons in 1990 and 1991 in the coastal waters of Oregon. Experimental water was collected using $5 \mathrm{l}$ Niskin bottles from a 7 to $9 \mathrm{~m}$ depth interval at 2 stations 9 (NH-5) and $18 \mathrm{~km}$ (NH-10) west of Newport

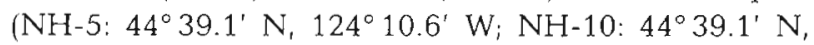
$124^{\circ} 17.1^{\prime} \mathrm{W}$ ). NH-10 was sampled on February 25 , 1990 through May 8, 1990, on October 11, 1990 and on January 22, 1991. NH-5 was sampled on all other dates. The water was collected using 51 Niskin bottles which were rigged with silicon O-rings, springs and tubing. After collection, the water was gently poured through a funnel topped with a $200 \mu \mathrm{m}$ mesh (to exclude large zooplankton) and connected to a hose through which 201 carboys were filled bottom up. All handling of the water was done while wearing gloves, all equipment that was brought into contact with the water was acid washed and only silicon hoses were used. The carboys were brought back to shore while being shaded and cooled on board ship, placed in a 
$10^{\circ} \mathrm{C}$ environmental chamber where the dilution experiments were set up ca $3 \mathrm{~h}$ after collection. Water for the dilutions was first prefiltered through a $20 \mu \mathrm{m}$ mesh, then gravity filtered through 3 PVC filter manifolds which contained $147 \mathrm{~mm}, 0.2 \mu \mathrm{m}$ polycarbonate filters (Poretics Corp.). Depending on ambient biomass, the filters were changed once or twice during the filtration process. Populations of plankton were diluted in replicate $1 \mathrm{l}$ polycarbonate bottles with the filtered seawater to achieve $10,40,70$ and $100 \%$ of the original seawater. Experiments from April 12 through July 10 , 1990, had an additional $25 \%$ dilution step. The bottles were first filled with the filtered water, then the undiluted water was carefully siphoned into the bottles, and care was taken to keep the siphon submerged to avoid bubbles. The dilutions were incubated for $24 \mathrm{~h}$ on a plankton wheel that was rotated at ca $1 \mathrm{rpm}$. before April 13, 1991, and from then on at ca $0.2 \mathrm{rpm}$. The light intensity (PAR, fluorescent tubes) of incubation was around $30 \mu \mathrm{mol}$ photons $\mathrm{m}^{-2} \mathrm{~s}^{-1}$ before August 7, 1990, then between 100 and $150 \mu \mathrm{mol}$ photons $\mathrm{m}^{-2} \mathrm{~s}^{-1}$ for the rest of the experiments. This light intensity was chosen to represent an average light intensity in the euphotic zone (see 'Results'). The light period was adjusted to in situ day length.

In addition to the regular dilutions, several control experiments were conducted. Tests for nitrogen limitation were carried out using a replicate set of dilutions inoculated with 1 or $2 \mu \mathrm{M} \mathrm{NH} \mathrm{NH}_{4} \mathrm{Cl}$ in all experiments from August 7, 1990. Tests for the effect of light intensity were carried out on several occasions. On December 13,1990, when the bottles of a replicate set of dilutions were screened with 1 layer of neutral density screen ( $30 \%$ reduction in light intensity) to determine if light adaptation would alter the outcome of the experiments. From April 13, 1991, 2 replicate bottles with undiluted water were screened in the same manner. Additional experiments tested if choreotrich ciliates experienced mortality when coming into contact with the airspace in the bottles. From August 21, 1990, a replicate set of bottles with undiluted seawater was incubated without any airspace, using parafilm to seal the bottles before closing them (D. Gifford pers. comm.).

All incubation bottles were sampled at the beginning and the end of the incubation period in triplicate for chlorophyll a (chl a). Ambient levels of chl a were also determined and size fractioned using a $20 \mu \mathrm{m}$ Nitex mesh. Water samples $(20$ to $100 \mathrm{ml}$ ) were filtered onto Whatman $\mathrm{GF} / \mathrm{F}$ filters with some $\mathrm{MgCO}_{3}$, the chlorophyll in the particulate fraction was extracted in $90 \%$ acetone for $24 \mathrm{~h}$ at $4^{\circ} \mathrm{C}$ and measured with a Turner 10 designs fluorometer. $\mathrm{C} / \mathrm{chl}$ ratios were calculated from the percentage of phytoplankton $>20 \mu \mathrm{m}$ according to Neuer \& Franks (1993). The first replicates of the un- diluted seawater were sampled for nitrate and initial and final subsamples for microscopy were drawn. For details of the nitrate analysis see Neuer \& Franks (1993). The microscopy samples were preserved in $2 \%$ glutaraldehyde, and, for most experiments conducted in 1991, a replicate sample was preserved with $10 \%$ acid Lugol's solution (see Throndsen 1978). The glutaraldehyde samples $(15$ to $30 \mathrm{ml}$ depending on ambient phytoplankton biomass) were filtered at ca $100 \mathrm{~mm} \mathrm{Hg}$ onto black $0.2 \mu \mathrm{m}$ polycarbonate filters (Poretics Corp.), stained with DAPI (end concentration $0.2 \mathrm{mg} \mathrm{l}^{-1}$; Porter \& Feig 1980) and processed according to Booth (1987). The slides were kept frozen at $-80^{\circ} \mathrm{C}$ until analysis.

We used the Bakun upwelling index (Bakun 1973) from $45^{\circ} \mathrm{N}, 125^{\circ} \mathrm{W}$ (made available by the NOAA/ NMFS Pacific Fisheries Environmental group, Monterey, California) as a measure of the strength of the wind-induced coastal upwelling. This index determines the Ekman transport directed offshore and has the units of $\mathrm{m}^{3} \mathrm{~s}^{-1}$ per $100 \mathrm{~m}$ of coastline. A positive upwelling index is an indication of how much water is driven offshore to be replaced by deeper water. Analogously, a negative Bakun index implies downwelling. The Bakun indices are presented as weekly averages. Compared to local wind data, the Bakun index is computed over larger spatial and temporal scales and gives a more damped estimation of local upwelling phenomena (Small \& Menzies 1981). On most cruises, a portable CTD (OS-100) was deployed to determine water column profiles of temperature, salinity and $\sigma_{\mathrm{t}}$. Light depths were determined using a Secchi disk.

Counting and statistical analysis. Protists of the following functional/taxonomic categories were counted: heterotrophic gymnodinoid and thecate dinoflagellates (Dodge 1982), autotrophic dinoflagellates including thecate and gymnodoid forms, choreotrich mixotrophic and heterotrophic ciliates (Montagnes \& Lynn 1991), heterotrophic nanoflagellates and the autotrophic ciliate Mesodinium rubrum (see Table 2). All groups were counted in the glutaraldehyde samples using a ZEISS epifluorescence microscope with bluelight (ZEISS filter set no. 487701) and UV (no. 487709) excitation. The different groups were distinguished by the autofluorescence of their respective photosynthetic pigments under blue-light excitation, along with the greenish autofluorescence of glutaraldehyde-fixed cells when excited with blue light, and the blue fluorescence of the DAPI-stained nuclei under UV-light excitation. The greenish autofluorescence of glutaraldehyde-fixed cells is not to be confused with the green-fluorescing dinoflagellates reported by Shapiro et al. (1989), even though these cells were also present in the coastal waters off Oregon and counted within the gymnodinoid dinoflagellates. Choreotrich ciliates and thecate dinoflagellates were also counted in the 
Lugol samples (settling volume $10 \mathrm{ml}$ or $50 \mathrm{ml}$ ) on a WILD inverted microscope. Cells belonging to each category were counted in groups of approximately equal size (range 2 to $10 \mu \mathrm{m}$, depending on cell size). Using the average cell diameter of each group, biovolume was calculated using appropriate geometrical shapes (Edler 1979). The biovolume of the individual groups (with the exception of thecate dinoflagellates) was then corrected for shrinkage with the following factors: Gymnodinoids $\times 1.25$ (Jerome et al. 1993; since shrinkage was not determined for glutaraldehyde, the shrinkage factor was taken from Gymnodinum sangineum fixed with $0.6 \%$ acid Lugol's solution; as shown in their study, both fixatives when compared in ciliates caused similar shrinkage); choreotrich ciliates $x$ 1.54 (for glutaraldehyde fixed cells; Choi \& Stoecker 1989); and nanoflagellates $\times 2.2$ (Choi \& Stoecker 1989). After this correction for fixation-induced shrinkage, biovolume was converted to carbon units using a ratio of 0.11 (Strathmann 1967).

We calculated confidence intervals around single counts of organism abundance based on a Poisson distribution of randomly distributed organisms (Lund et al. 1958, Venrick 1978). A Poisson distribution should exist within the dilution bottles which were carefully mixed before sampling. Juhl (1991) also concludes that if at least 30 organisms are counted, replicate slides are unnecessary to improve the accuracy of the abundance estimate. When replicate slides were counted, the biomass estimates were within the $95 \%$ confidence interval calculated assuming the Poisson distribution.

No consistent significant difference was found for the counts of choreotrich ciliates in glutaraldehyde versus Lugol samples and we used the counts from the glutaraldehyde samples for further analysis. Thecate dinoflagellates, on the other hand, apparently were underestimated by up to a factor of 2 to 3 in the glutaraldehyde samples. This may be due to better visibility of thecate forms in the Lugol samples. Subsequently, thecate dinoflagellate counts and biomass estimates were taken from the Lugol counts when available.

Counts of choreotrich ciliates were also compared from final samples of bottles with and without airspace. The comparison showed that in some cases ciliates in the bottles without an airspace increased in abundance, while the ciliate population in the bottles with air did not. Obviously, in some experiments ciliate mortality did occur in the bottles with an airspace but the cells were usually not reduced below initial levels. There was never a significant difference ( $t$-test, $p \leq 0.05$ ) when comparing changes in chlorophyll biomass during the incubation period of the bottles with and without airspace.

Net growth rates of the protozooplankton were determined in the bottles without airspace from initial and final counts for heterotrophic gymnodinoids, thecate dinoflagellates and heterotrophic nanoflagellates if initial and final counts were significantly different. It was assumed that the exponential growth equation could be applied.

\section{RESULTS}

\section{Environmental conditions}

In both 1990 and 1991, offshore transport of water as expressed by the Bakun index was strongest and most consistent during summer, whereas during winter, winds were predominantly unfavourable for upwelling (Fig. 1). But throughout both years, wind reversals were common and the strength of off-or onshore flow varied considerably. Based upon mean indices for summer, Small \& Menzies (1981) determined that upwelling indices greater than 50 (in Fig. 1 greater than 5) reflected strong upwelling, and those less than 50 reflected little or no upwelling. Strong upwelling peri-

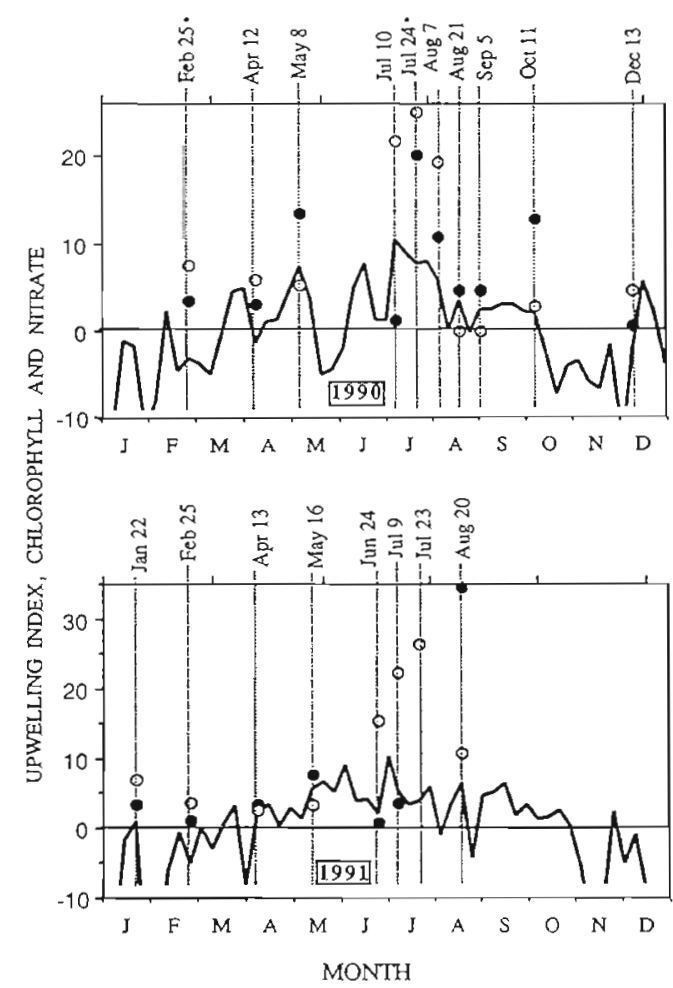

Fig. 1 Upwelling indices $\left(0.1 \mathrm{~m}^{2} \mathrm{~s}^{-1}\right.$, weekly averages, solid line) and nitrate $\left(\mu \mathrm{mol} \mathrm{l}^{-1}, 0\right)$ and chlorophyll $\left(\mu \mathrm{g} \mathrm{l}^{-1}, \bullet\right)$ concentrations measured on the sampling dates in 1990 and 1991. The Bakun upwelling index was divided by 10 to fit on the same scale. An upwelling index of greater than 5 indicates strong upwelling, below 5 weak or no upwelling. On July 23, 1991, chlorophyll was off scale with $55.3 \mu \mathrm{g} \mathrm{l}^{-1}$. "No experimental data available 
Table 1. Results of the dilution experiments and initial conditions of the undiluted seawater. Instantaneous phytoplankton growth rates $\mu$, grazing rates $g$, correlation coefficient $\mathrm{R}^{2}$ of the linear regression model, chlorophyll, ammonium and nitrate concentrations and $\sigma_{t} .+\mathrm{N}$ : replicate dilution experiment with added ammonium; screened: replicate set of dilutions screened by 1 layer of neutral density screen; NA: not available

\begin{tabular}{|c|c|c|c|c|c|c|c|c|}
\hline Date & $\begin{array}{c}\mu( \pm 95 \% C I) \\
\left(d^{-1}\right)\end{array}$ & $\begin{array}{c}g( \pm 95 \% \mathrm{CI}) \\
\left(\mathrm{d}^{-1}\right)\end{array}$ & $\mathrm{R}^{2}$ & $\begin{array}{c}\text { Chl a } \\
\left(\mu \mathrm{g} \mathrm{l}^{-1}\right)\end{array}$ & $\begin{array}{l}\text { Fraction chl a } \\
\quad>20 \mu \mathrm{m}\end{array}$ & $\begin{array}{c}\mathrm{NH}_{4}^{+}-\mathrm{N} \\
\left(\mu \mathrm{mol} 1^{-1}\right)\end{array}$ & $\begin{array}{c}\mathrm{NO}_{3}^{-}-\mathrm{N} \\
\left(\mu \mathrm{mol} \mathrm{l} l^{-1}\right)\end{array}$ & $\sigma_{\mathrm{t}}$ \\
\hline \multicolumn{9}{|l|}{1990} \\
\hline February 25 & NA & NA & & 3.4 & 0.47 & $0.22^{a}$ & $7.5^{\mathrm{a}}$ & NA \\
\hline April 12 & $0.33(0.14)$ & $0.12(0.23)$ & 0.14 & 3.0 & $0.07^{\mathrm{a}}$ & $0.4^{\mathrm{a}}$ & $5.8^{\mathrm{a}}$ & $22.06^{\mathrm{a}}$ \\
\hline May 8 & $-0.03(0.22)$ & $-0.12(0.35)$ & 0.06 & 13.3 & $0.84^{a}$ & $0.06^{\mathrm{a}}$ & $5.2^{\mathrm{a}}$ & $24.39^{\mathrm{a}}$ \\
\hline July 10 & $0.64(0.18)$ & $0.85(0.30)$ & $0.84^{\circ}$ & 1.1 & $0.58^{a}$ & 2.3 & $21.8^{\mathrm{d}}$ & $25.71^{\mathrm{a}}$ \\
\hline July 24 & NA & NA & & 20.2 & $0.92^{\circ}$ & $0.4^{\mathrm{a}}$ & $25.0^{\mathrm{a}}$ & $26.32^{\mathrm{d}}$ \\
\hline $\begin{array}{l}\text { August } 7 \\
+\mathrm{N}\end{array}$ & $\begin{array}{l}1.58(0.67) \\
1.73(0.30)\end{array}$ & $\begin{array}{l}0.88(1.00) \\
0.97(0.44)\end{array}$ & $\begin{array}{l}0.60 \\
0.90^{\circ}\end{array}$ & 10.7 & $0.53^{a}$ & $2.5^{\mathrm{a}}$ & 17.3 & $25.62^{\circ}$ \\
\hline $\begin{array}{l}\text { August } 21 \\
+\mathrm{N}\end{array}$ & $\begin{array}{l}-0.79(0.37) \\
-0.64(0.61)\end{array}$ & $\begin{array}{l}0.17(0.54) \\
0.37(0.98)\end{array}$ & $\begin{array}{l}0.09 \\
0.13\end{array}$ & 4.6 & $0.75^{\mathrm{a}}$ & 0.2 & 0 & $24.82^{\mathrm{a}}$ \\
\hline $\begin{array}{l}\text { September } 5 \\
+\mathrm{N}\end{array}$ & $\begin{array}{r}-0.12(0.23) \\
0.15(0.12)\end{array}$ & $\begin{array}{l}0.03(0.36) \\
0.10(0.23)\end{array}$ & $\begin{array}{l}0.01 \\
0.18\end{array}$ & 4.6 & $0.70^{a}$ & 0.2 & 0 & NA \\
\hline $\begin{array}{l}\text { October } 11 \\
+\mathrm{N}\end{array}$ & $\begin{array}{l}-0.37(0.06) \\
-0.47(0.18)\end{array}$ & $\begin{array}{r}0.04(0.13) \\
-0.11(0.28)\end{array}$ & $\begin{array}{l}0.09 \\
0.16\end{array}$ & 12.8 & $0.93^{\circ}$ & 0.4 & 2.8 & $25.19^{\circ}$ \\
\hline $\begin{array}{c}\text { December } 13+N \\
\text { Screened }+N\end{array}$ & $\begin{array}{l}0.24(0.13) \\
0.21(0.13)\end{array}$ & $\begin{array}{l}0.07(0.21) \\
0.05(0.21)\end{array}$ & $\begin{array}{l}0.13 \\
0.06\end{array}$ & 0.6 & $0.31^{\mathrm{a}}$ & 1.4 & 4.7 & $24.73^{\mathrm{a}}$ \\
\hline \multicolumn{9}{|l|}{1991} \\
\hline $\begin{array}{l}\text { January } 22 \\
+N\end{array}$ & $\begin{array}{l}0.20(0.10) \\
0.18(0.10)\end{array}$ & $\begin{array}{l}0.16(0.15) \\
0.09(0.15)\end{array}$ & $\begin{array}{l}0.53^{\circ} \\
0.28\end{array}$ & 3.3 & $0.06^{\mathrm{a}}$ & 0.2 & 6.8 & $24.74^{\mathrm{a}}$ \\
\hline $\begin{array}{l}\text { February } 25 \\
+\mathrm{N}\end{array}$ & $\begin{array}{l}0.39(0.24) \\
0.42(0.20)\end{array}$ & $\begin{array}{l}0.03(0.39) \\
0.08(0.29)\end{array}$ & $\begin{array}{l}0.01 \\
0.07\end{array}$ & 1.0 & $0.42^{\mathrm{a}}$ & 0.5 & 3.65 & NA \\
\hline $\begin{array}{l}\text { April } 13 \\
+\mathrm{N}\end{array}$ & $\begin{array}{l}0.61(0.13) \\
0.62(0.21)\end{array}$ & $\begin{array}{l}0.11(0.21) \\
0.09(0.31)\end{array}$ & $\begin{array}{l}0.28 \\
0.10\end{array}$ & 3.4 & $0.82^{a}$ & 0.95 & 2.6 & NA \\
\hline $\begin{array}{l}\text { May } 16 \\
+\mathrm{N}\end{array}$ & $\begin{array}{l}0.83(0.08) \\
0.71(0.25)\end{array}$ & $\begin{array}{l}0.15(0.11) \\
0.03(0.33)\end{array}$ & $\begin{array}{l}0.75^{\circ} \\
0.02\end{array}$ & 7.6 & $0.62^{a}$ & 0.2 & 3.4 & $23.89^{\circ}$ \\
\hline June 24 & \multicolumn{2}{|c|}{ Mostly phaeopigment } & & 0.7 & $0.78^{\text {a }}$ & 0.95 & 15.2 & $25.92^{a}$ \\
\hline $\begin{array}{l}\text { July } 9 \\
+N\end{array}$ & $\begin{array}{l}0.86(0.12) \\
0.81(0.05)\end{array}$ & $\begin{array}{l}0.07(0.20) \\
0.15(0.07)\end{array}$ & $\begin{array}{l}0.11 \\
0.79^{\circ}\end{array}$ & 3.5 & $0.20^{\mathrm{a}}$ & 0.1 & 22.2 & $25.90^{\mathrm{a}}$ \\
\hline $\begin{array}{l}\text { July } 23 \\
+\mathrm{N}\end{array}$ & $\begin{array}{l}1.03(0.20) \\
1.00(0.07)\end{array}$ & $\begin{array}{l}0.26(0.27) \\
0.18(0.11)\end{array}$ & $\begin{array}{l}0.44 \\
0.73\end{array}$ & 55.3 & $0.88^{a}$ & 0.3 & 26.4 & NA \\
\hline August 20 & $0.67(0.10)$ & $0.33(0.15)$ & $0.83^{\circ}$ & 34.6 & $0.81^{\mathrm{a}}$ & 1.1 & 10.7 & $25.27^{\mathrm{a}}$ \\
\hline
\end{tabular}

ods occurred in both years, mostly between May and August. Nitrate levels measured were above $10 \mu \mathrm{M}$ in July and August and chlorophyll levels were variable, from 1 to $55 \mathrm{\mu g} \mathrm{l}^{-1}$ (Fig. 1, Table 1). Both upwelling events that were sampled in May 1990 and 1991 showed low nitrate values, however, and chlorophyll levels were intermediate $\left(13\right.$ and $8 \mu \mathrm{g} \mathrm{l}^{-1}$, respectively). On all other sampling dates, when there was low or no upwelling, nitrate values were around or below $5 \mu \mathrm{M}$ and chlorophyll levels also around or below $5 \mathrm{\mu g} \mathrm{l}^{-1}$ (with the exception of October 11, 1990).

The summer permanent pycnocline that outcrops during strong upwelling events is given by a $\sigma_{t}$ interval between 25.5 and 26.0 (Small \& Menzies 1981, Huyer
1983). Only the upwelling events sampled on July 10 and 24 and August 7, 1990, as well as on July 10, 1991 (no CTD data available for July 23, 1991), showed density values in that interval (Table 1, Fig. 2C). On June 25,1991 , the 7 to $9 \mathrm{~m}$ sampling interval was within the summer permanent pycnocline, but was apparently covered by a shallow lens of Columbia River water $\left[\sigma_{t}<23.4\right.$, which was used by Small \& Ramberg (cited in Small \& Menzies 1981) as an indicator of the shoreward boundary of the Columbia River plume, Fig. 2B]. The chlorophyll on that sampling date consisted largely of phaeopigment, and a phytoplankton growth rate could not be determined (Table 1). On all other upwelling events, the water sampled was less dense 
Temperature ${ }^{\circ} \mathrm{C}$

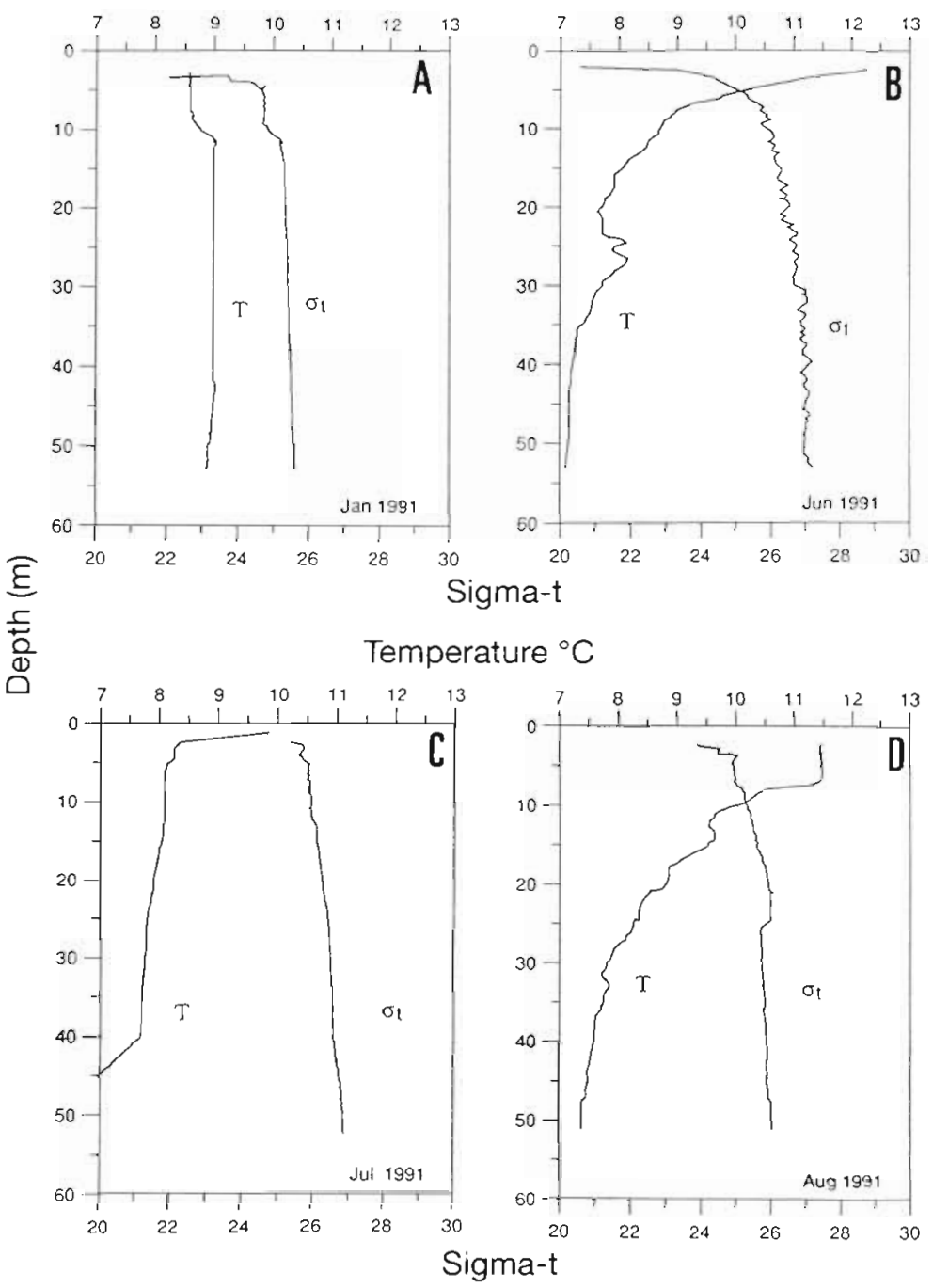

Fig. 2. Selected water column profiles of temperature $\left(T,{ }^{\circ} \mathrm{C}\right)$ and $\sigma_{\mathrm{t}}$ of the sampling dates (A) January 22, (B) June 24, (C) July 7 and (D) August 20 , 1991

than that of the summer permanent pycnocline, indicative of a shallower origin of the upwelled water, but there was no evidence of Columbia River influence (e.g. August 20, 1991; Table 1, Fig. 2D). On August 20 , 1991, the surface waters were warmer and the mixed layer deeper compared to recently upwelled water. The high chlorophyll and nutrient levels indicated that the water had been upwelled some time before the sampling date and had time to stabilize due to solar heating. A typical winter situation is depicted in Fig. $2 \mathrm{~A}$; on January 22,1991 , the mixed layer was not very pronounced and the water column was fairly homogeneous. The rapid decrease in $\sigma_{t}$ in the surface could have been caused by a decrease of salinity due to rain.

According to Secchi-disk measurements, the sampling interval received between 5 and $30 \%$ of incident surface light intensity, depending on ambient phytoplankton biomass levels. Surface light levels as measured with a LICOR $2 \pi$ sensor varied between 600 and $1000 \mu \mathrm{mol}$ photons $\mathrm{m}^{-2} \mathrm{~s}^{-1}$ in winter, and between 150 and $1500 \mu \mathrm{mol}$ photons $\mathrm{m}^{-2} \mathrm{~s}^{-1}$ in summer. The low light levels encountered in summer were due to foggy weather conditions common during coastal upwelling. Thus, even though highest light levels were reached during summer, light levels measured in winter were not consistently lower. It should also be noted that water temperatures in summer were between 8 and $11^{\circ} \mathrm{C}$, and in winter between 9 and $10^{\circ} \mathrm{C}$ (Fig. 2), showing that overall water temperatures only vary within a narrow range.

\section{Composition of grazer assemblage}

Protist groups were the most abundant grazers in the dilution experiments. Occasionally, nauplii, appendicularians, larval stages of benthic organisms, rotatorians and the predacious dinoflagellate Noctiluca scintillans were also observed during microscopic analyses of the dilution experiments, but they were always rare. The same was true for scuticociliates which were at times observed in the Lugol samples. Only the ciliate Tiarina fusus (Colepidae; Corliss 1979) was quantified and listed together with the choreotrichs in one group since its occurrence was restricted to late summer 1990 (August 21 and September 5) when it reached up to 1000 cells $1^{-1}$. Among the heterotrophic choreotrichs, only the tintinnids were identified to genus. The enumerated tintinnids belonged to the genera Salpingella, Tintinnus, Proplectella, Ptychocyclis, Tintinnopsis and Stenosomella (Wailes 1943). Among the mixotrophic choreotrichs, the genera Laboea and Tontonia constituted a large portion of the total count. The group 'heterotrophic gymnodinoids' included mainly cells of the genera Gymnodinium and Gyrodinium and spanned a wide size range. The smallest cells were about $10 \mu \mathrm{m}$ long, the largest ones up to $130 \mu \mathrm{m}$. The large gymnodinoids have characteristic nuclei that contain moniliform chromatin bands (Kofoid \& Swezy 1921) in contrast to the smaller forms whose nuclei appear granulated when DAPI stained. Heterotrophic thecate dinoflagellates included the genus Protoperidinium and other genera which likely belonged to the 'Diplopsalis' group (Dodge 1982, 
Dodge \& Toriumi 1993). On July 23, 1991, a round heterotrophic dinoflagellate with a diameter of about $30 \mu \mathrm{m}$ was abundant (3000 cells $\mathrm{l}^{-1}$ ) but it could not be further identified and it was not apparent if it was thecate. This dinoflagellate was not included in any group. The autotrophic dinoflagellates included autotrophic gymnodinoids and prorocentrales, and the genera Torodinium, Gonyaulax, Ceratium and Dinophysis could be distinguished. Occasionally during summer months, secondary cysts of Dissodinium cf. pseudocalani (Elbrächter \& Drebes 1978) were observed to contain up to 10 chlorophyll-containing dinospores per cyst resulting in up to 2000 dinospores $1^{-1}$. Heterotrophic nanoflagellates were only counted in size categories and not identified further. These cells spanned a size range of 2 to $20 \mu \mathrm{m}$ in length.

In terms of cell numbers, heterotrophic gymnodinoids, nanoflagellates and autotrophic dinoflagellates dominated the protist community in the upwelling region (Table 2). Their numbers did not vary consistently with upwelling status or season but highest numbers were observed during the upwelling season. The other enumerated protist groups were about an order of magnitude less abundant than the gymnodinoids and nanoflagellates. The autotrophic ciliate Mesodinium rubrum was more common in the nonupwelling season with a maximum (with $8 \times 10^{3}$ cells $\mathrm{l}^{-1}$ ) on April 12, 1990, than during upwelling events but never reached bloom-forming abundances (around $1 \times 10^{5} \mathrm{1}^{-1}$; Smith \& Barber 1979). Autotrophic dinoflagellates were comparable in cell number to heterotrophic dinoflagellates during the non-upwelling period and were less abundant, sometimes by an order of magnitude, during the upwelling season.

Total grazer biomass (Fig. 3) was variable during the year with highest and lowest numbers occurring during the upwelling season. Two samples from newly upwelled waters sampled in early July 1990 and 1991 had a very low grazer biomass. The highest biovolume of grazers was observed during August 21,1990 , when total grazer biomass was $20 \%$ of the combined phytoplankton and grazer biomass (in carbon). During bloom periods, the contribution of grazer biomass to total biomass was smallest (ca 1\%) and during the non-upwelling season, it ranged from 4 to $9 \%$. Gymnodinoids and thecate dinoflagellates reached their highest abundance during the upwelling period (Fig. 4). On August 21, 1990, gymnodinoids constituted $82 \%$ and on September 5, 1990, $57 \%$ of total grazer bioviolume. During most of 1991 . gymnodinoids contributed between 12 and $28 \%$ of total grazer biovolume. Choreotrichs were more conspicuous during the non-upwelling period when their biovolumes were fairly constant and contributed between 20 and $50 \%$ of total grazer biovolume. The highest biovolume was observed on April 12, 1990 , and the contribution to total grazer biovolume was $57 \%$. Nanoflagellate abundance was fairly high when compared to the biovolume of the other protists, albeit variable throughout the year, but again reached highest values during the upwelling season. Their contribution to total grazer biovolume was between 12 and 53\%, and highest in the freshly upwelled waters, with $75 \%$ in 1990 and $63 \%$ in 1991

Table 2. Initial abundances (cells $\mathrm{ml}^{-1}$ ) of functional/taxonomic categories of protists in the experimental water. $95 \%$ confidence interval of the estimate given in parentheses

\begin{tabular}{|c|c|c|c|c|c|c|c|}
\hline \multirow[t]{2}{*}{ Date } & \multirow{2}{*}{$\overline{\text { Gymnodinoids }}$} & \multirow{2}{*}{$\begin{array}{c}\text { Thetero } \\
\text { Thecate } \\
\text { dinoflagellates }\end{array}$} & \multirow{2}{*}{$\begin{array}{l}\text { troph } \\
\quad \text { Ciliates }\end{array}$} & \multirow[b]{2}{*}{ Nanoflagellates } & \multirow{2}{*}{$\begin{array}{c}\text { Mixotroph } \\
\text { Ciliates }\end{array}$} & \multicolumn{2}{|c|}{$\longrightarrow$ Autotroph $\longrightarrow$} \\
\hline & & & & & & Ciliates I & Dinoflagellates \\
\hline \multicolumn{8}{|l|}{1990} \\
\hline April 12 & $19(12-31)$ & $6(2-15)^{\circ}$ & $2(1-3)$ & $1760(1280-2410)$ & $8(5-10)$ & $2(1-3)$ & $47(35-65)$ \\
\hline July 10 & $6(4-9)$ & $\ll 1^{*}$ & $\ll 1$ & $1840(1470-2300)$ & 0 & $0.4(0.2-0.7)$ & $\ll 1$ \\
\hline August 7 & $17(12-23)$ & $0.4(0.2-0.8)^{*}$ & $1(0.7-2)$ & $4110(3110-5420)$ & $\ll 1$ & $7(5-9)$ & $5(3-9)$ \\
\hline August 21 & $58(48-69)$ & $3(2-4)^{\circ}$ & $0.8(0.5-1.2)$ & $995(729-1353)$ & $1.2(0.9-1.7)$ & $0.1(0.1-0.4)$ & $5(3-8)$ \\
\hline September 5 & $39(32-48)$ & $\ll 1^{\circ}$ & $4(3-5)$ & $2490(2060-3000)$ & $0.9(0.4-1.6)$ & $\ll 1$ & $24(18-33)$ \\
\hline December 13 & $6(4-9)$ & $\ll 1^{\circ}$ & $0.9(0.6-1.3)$ & $290(184-452)$ & $0.3(0.2-0.6)$ & $\ll 1$ & $3(2-6)$ \\
\hline \multicolumn{8}{|l|}{1991} \\
\hline January 22 & $53(42-67)$ & $0.2(0-1)^{\bullet}$ & $1(0.7-1.5)$ & $1370(1120-1680)$ & $2(4-1)$ & $0.7(0.4-1)$ & $50(39-64)$ \\
\hline February 25 & $9(7-12)$ & $\ll 1$ & $0.5(0.3-0.9)$ & $1300(980-1710)$ & $0.6(0.4-1)$ & $4(3-5)$ & $10(7-15)$ \\
\hline April 13 & $34(29-40)$ & $0.4(0.3-0.7)$ & $5(4-6)$ & $992(777-1263)$ & $\ll 1$ & $0.3(0.2-0.5)$ & $4(3-6)$ \\
\hline May 16 & $44(37-54)$ & $1.4(1.1-1.8)$ & $5(4-7)$ & $1870(1400-2490)$ & $1.1(0.8-1.6)$ & $0.3(0-0.5)$ & $30(23-40)$ \\
\hline July 9 & $9(7-12)$ & $0.1(0-0.2)$ & $1(0.7-2)$ & $832(695-996)$ & $\ll 1$ & $0.7(0.4-1)$ & $31(22-43)$ \\
\hline July 23 & $34(26-44)$ & $0.8(0.4-1.6)$ & $4(3-5)$ & $1360(980-1880)$ & $0.2(0-0.5)$ & 0 & $8(4-18)$ \\
\hline August 20 & $64(53-78)$ & $1.5(0.7-3)^{\circ}$ & $0.8(0.4-1.4)$ & $1030(790-1350)$ & $\ll 1$ & 0 & $0.6(0.3-1)$ \\
\hline
\end{tabular}




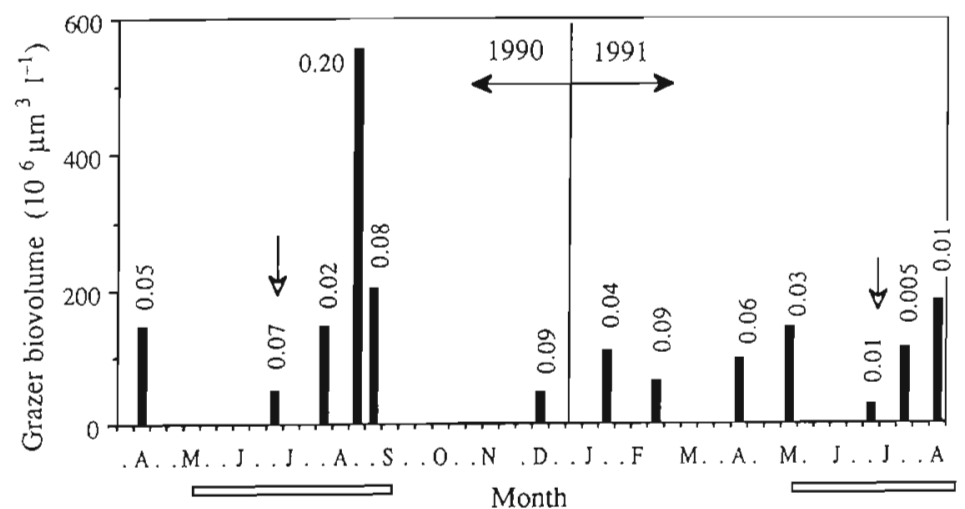

Fig. 3. Total grazer biovolume $\left(\times 10^{6} \mu^{3} \mathrm{~m}^{-1}\right.$, initial numbers $)$ counted in the experimental water during 1990 and 1991 . Numbers over bars are the fractions of the contribution of grazer biomass to the combined biomass of grazers and phytoplankton (in carbon). Horizontal bars show the duration of the upwelling season. Arrows indicate when newly upwelled water was sampled

The proportion of gymnodinoids greater than $25 \mu \mathrm{m}$ in length (Fig. 4) was highest during the upwelling period (exception April 13, 1991) and correlated strongly with the proportion of chlorophyll biomass greater than $20 \mu \mathrm{m}\left(\mathrm{R}^{2}=0.71, \mathrm{n}=12\right)$.

\section{Dilution experiments: controls and assumptions}

Exponential growth equation cannot be applied

On some occasions, phytoplankton declined during the incubations, such as on August 21, and October 11.
1990. Negative phytoplankton growth was also measured on May 8 and September 5 , 1990 (the replicate without added ammonium), but was not significantly different from zero (Table 1). The high fraction of chlorophyll greater than $20 \mu \mathrm{m}$ shows that the phytoplankton population consisted mainly of chain-forming or large solitary diatoms (confirmed by microscopic observations). Nitrate was either low or not measurable (Table 1, Fig. 1) and it was likely that the phytoplankton population was in a state of physiological decline. This decline caused large variability among the replicates and represents a loss factor that cannot be modelled exponentially, therefore the assumption that growth and grazing rates can be described using the exponential growth equation cannot be satisfied. None of the grazing rates determined under those conditions were significantly different from zero and, in some cases, the slope of the linear regression was positive (shown as negative grazing rates in Table 1).

\section{Nitrogen limitation}

We compared the 2 straight line regression equations of the dilutions with and without added ammonium by applying tests to determine if either intercept (phytoplankton growth rate) or slope (grazing rate) were significantly different from each other (tests outlined in Kleinbaum \& Kupper 1978). Only the inter-
Gymnodinoids

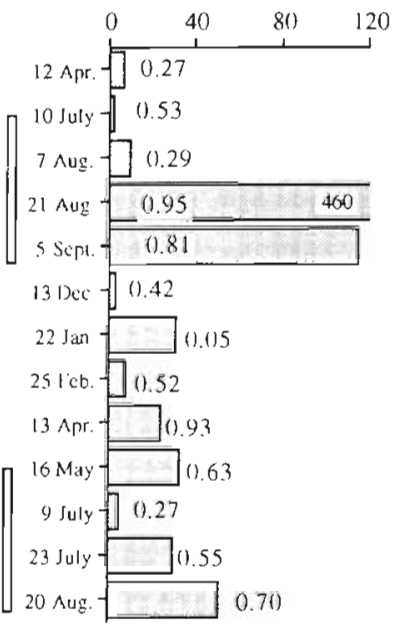

Thecate dinoflagellates

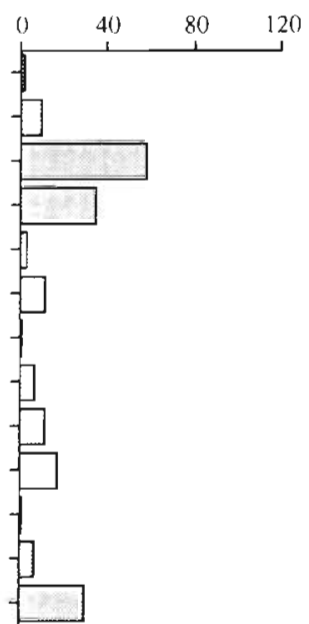

Choreotrich ciliates

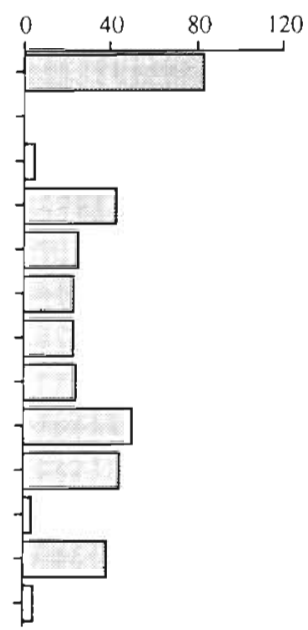

Nanoflagellates

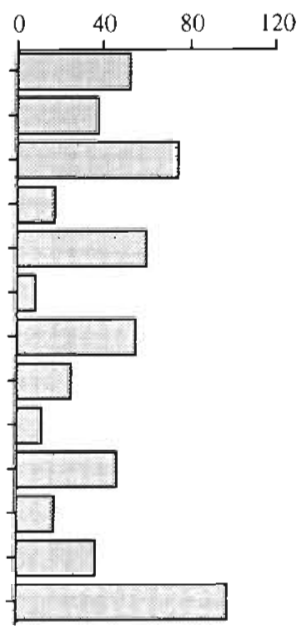

Fig. 4. Biovolume $\left(\times 10^{6} \mathrm{\mu m}^{3} \mathrm{I}^{-1}\right)$ of the different groups of grazers (initial numbers) counted in the experimental water in 1990 and 1991. Vertical bars show the duration of the upwelling season. Fraction of gymnodinoids larger than $25 \mu \mathrm{m}$ is shown for each gymnodinoid count 


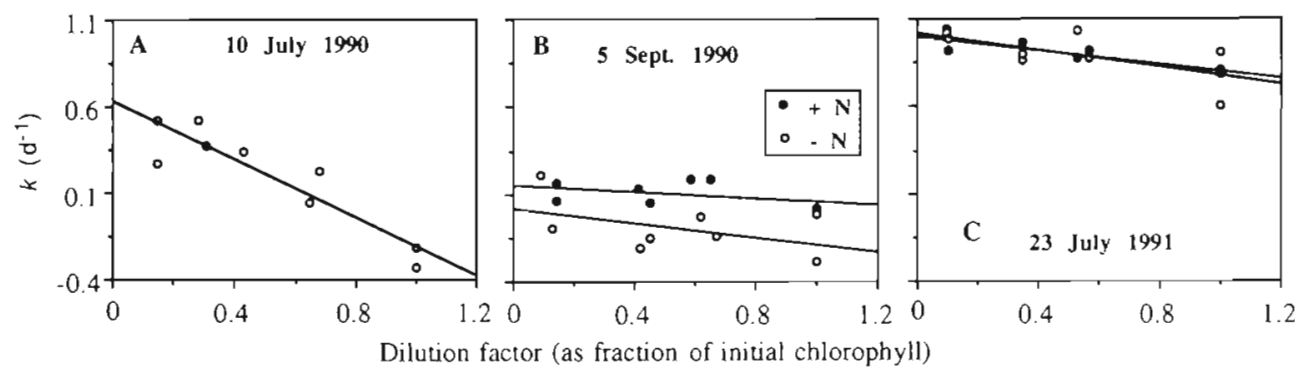

Fig. 5. Selected dilution experiments. Apparent phytoplankton growth rate is plotted against the proportion of undiluted initial chlorophyll. The intercept of the regression line with the $\gamma$-axis is the instantaneous phytoplankton growth rate $\mu\left(\mathrm{d}^{-1}\right)$ and the slope is the grazing rate $g\left(\mathrm{~d}^{-1}\right)$. (A) The highest dilutions indicate that a feeding threshold occurred (see text for further explanation) (B) Nitrogen limitation. Replicate dilution series with $2 \mu \mathrm{M}$ ammonium ( $\bullet$ ) and without added ammonium (O). The phytoplankton community in this experiment was found to have been ammonium-limited based on the statistical difference of $\mu$ in the 2 treatments (see Table 1). (C) No nitrogen limitation. Symbols as in (B)

cepts of the experiment conducted on September 5 , 1990, (Fig. 5B) were significantly different from each other ( $\mathrm{p} \leq 0.05$ ), all the other experiments showed no significant difference of either slope or intercept. Thus, the September 5 experiment provides evidence that ammonium was limiting phytoplankton growth in situ since phytoplankton growth was enhanced in all dilutions (Fig. 5B). The other experiments did not provide evidence that the phytoplankton community was nitrogen limited. It is interesting to note that the replicability of experiments conducted during the phytoplankton bloom and prebloom period when nitrate levels were high (August 7, 1990; July 9, July 23, 1991) improved when ammonium was added (higher $\mathrm{R}^{2}$, grazing rates significantly different from zero). The exception was the experiment conducted on August 20, 1991, when the treatment without added ammonium showed significant results; but on this date the ambient ammonium levels were high and comparable to those of the ammonium treatments. On Jauary 22 , 19 and May 16, 1991, when nitrate levels were low, only treatments without added ammonium resulted in significant phytoplankton growth and grazing rates.

\section{Nonlinearity of grazing rates}

The experiments were conducted during both upwelling and non-upwelling periods in which chlorophyll biomass levels varied from 0.6 to $55.3 \mathrm{\mu g} \mathrm{l}^{-1}$ (Table 1). At low ambient chlorophyll, further reduction of phytoplankton biomass levels in the dilutions could result in feeding thresholds of the grazer community. When plotting phytoplankton growth versus dilution factor, a feeding threshold would be apparent if diluting the plankton community did not decrease grazing pressure and the apparent phytoplankton growth rate remained unchanged (Gifford 1988, Gallegos 1989). Alternatively, when phytoplankton biomass is high, saturated feeding responses by the grazers could also result in a departure from linearity because grazing pressure on the phytoplankton would not be reduced as a linear function of dilution (Gallegos 1989). There was no evidence for saturated feeding responses in our experiments, not even in the 2 last experiments when chl a standing stock was 35 and $55 \mu \mathrm{g} \mathrm{l}^{-1}$, respectively (Fig. 5C, Table 1). Possible feeding thresholds might not have been detected because not enough highly diluted incubations were performed (see Gallegos 1989), though in the experiment of July 10, 1990 a threshold might have occurred (Fig. 5A). With the exception of December 13, 1990, when grazing rates were not detectable, all other experiments were conducted with higher phytoplankton standing stocks and the occurrence of feeding thresholds is not to be expected.

\section{Microzooplankton numbers unchanged during the incubation}

We tested this assumption by determining net growth rates of the protists during the dilution experiment incubation, based on initial and final biovolume estimates in the undiluted bottles (Table 3 ). We found that protist biomass increased in some experiments. Choreotrichs were not included since possible mortality in the bottles might have biased the final biovolume estimates (see 'Methods'). During 1990, gymnodinoids grew on August 7 but were in rapid decline on August 21 (the numbers for the July date were too low to estimate a change in biomass). During 1991, we observed growth on almost all dates. Growth rates were high and ranged from 0.7 to $1.2 \mathrm{~d}^{-1}$ (1 to 1.7 doublings $\mathrm{d}^{-1}$ ). For the thecate dinoflagellates, a net change could not be determined during the incubations, possibly because these cells were never very abundant and possessed large confidence intervals on 
Table 3. Net instantaneous growth rates, $\mu(95 \% \mathrm{CI})$, of 2 different grazer populations based on changes of biovolume during the incubation period. -: no significant change

\begin{tabular}{|lcc|}
\hline Date & $\begin{array}{c}\text { Gymnodinoid } \\
\text { dinoflagellates }\end{array}$ & $\begin{array}{c}\text { Nano- } \\
\text { flagellates }\end{array}$ \\
\hline 1990 & - & - \\
April 12 & - & - \\
July 10 & 1.0 & 1.2 \\
August 7 & $(0.4-1.6)$ & $(0.7-1.7)$ \\
August 21 & -1.2 & 0.8 \\
September 5 & $(-1.6$ to -0.9$)$ & $(0.2-1.4)$ \\
December 13 & - & - \\
1991 & - & - \\
January 22 & - & - \\
February 25 & 1.0 & - \\
April 13 & $(0.5-1.4)$ & $(0.4-1.5)$ \\
May 16 & 0.8 & - \\
July 9 & $(0.4-1.2)$ & 0.7 \\
July 23 & 0.8 & $(0.2-1.2)$ \\
August 20 & $(0.4-1.2)$ & - \\
& 1.2 & - \\
\hline
\end{tabular}

initial and final counts. The nanoflagellate population grew on 4 occasions, with growth rates comparable to those of the gymnodinoids. Grazing rates had to be corrected for the experiments in which grazer abundance increased. Based upon estimates of population clearance rates, herbivory by the gymnodinioid dinoflagellate population was found to outweigh greatly herbivory by nanoflagellates (Neuer 1992). We therefore corrected grazing rates by the net growth of gymnodinoids in those experiments that yielded a grazing rate significantly different from zero. This was done by multiplying $g$ with the ratio of the initial abundance divided by the time-averaged abundance of gymnodinoids (modified after Landry 1993). This assumes that grazer increase was constant over all dilutions. Only on August 21, 1990, was the corrected grazing rate significantly different from the uncorrected one (Table 4 ).

In addition to the assumptions outlined above, the use of changes in chl a to calculate bulk phytoplankton growth rate could lead to erroneous results if the phytoplankton population were in a state of photoadaptation and cellular chl a levels were changing during the course of the experiments. Even though the measure of zooplankton grazing rate is not affected by
Table 4 . Grazing rates $\left(g^{*}\right)$ corrected by growth of gymnodinoid dinoflagellates

\begin{tabular}{|lc|}
\hline Date & $g \cdot\left(\mathrm{d}^{-1}\right)$ \\
\hline $\mathbf{1 9 9 0}$ & \\
August 7 & 0.56 \\
1991 & \\
May 16 & 0.10 \\
July 9 & 0.09 \\
July 23 & 0.12 \\
August 20 & 0.21 \\
\hline
\end{tabular}

this potential artifact, it was addressed in the experiments. Shaded controls of undiluted seawater, and 1 experiment in which all dilution bottles were shaded by 1 layer of neutral density screen (December 13 , 1990; Table 1), showed no significant difference in phytoplankton growth rates. If the light intensity of incubation was causing a decrease in cellular chlorophyll levels, the apparent growth rate measured should have been smaller than that of the shaded replicate. If, on the other hand, the light intensity of incubation caused an increase in cellular chl a levels, then the growth rates measured in the shaded replicate should have been larger. The results show that neither case of photoadaptation influenced growth rate estimates.

\section{Herbivory and phytoplankton growth rates}

Phytoplankton growth rates were high during the upwelling periods, ranging from 0.64 to $1.73 \mathrm{~d}^{-1}$ (Table 1). The exceptions were August 21 and September 5, 1990, when phytoplankton either did not grow or grew slowly $\left(0.15 \mathrm{~d}^{-1}\right)$. These 2 dates were accompanied by very weak upwelling and wind reversals (Fig. 1) and nitrate was depleted in the mixed layer. The 2 sampling dates in May coincided with a period of strong upwelling, but nitrate levels were not elevated and in 1990 no phytoplankton growth could be determined. Grazing rates were variable during the upwelling season, ranging from zero on those dates when no phytoplankton growth could be determined, to a maximum of $0.56 \mathrm{~d}^{-1}$ on August 7, 1990 (Tables 1 \& 4). In winter (from December 1990 to April 1991), both phytoplankton growth rates and grazing rates were low. Rates of herbivory were mostly insignificant with the exception of the January 22, 1991, experiment (Table 1). However, it should be noted that grazing rates determined in the treatments with and without added ammonium differed less than indicated by the $95 \%$ confidence interval. Thus, even though no statistically significant grazing rates were obtained in most of the experiments conducted in winter, the measured 
low grazing rates were probably a good estimate of the true microzooplankton grazing occurring in situ.

\section{DISCUSSION}

\section{Rates of growth and grazing during different stages of phytoplankton bloom development}

Three distinct stages of phytoplankton bloom development can be distinguished during upwelling events. The first stage occurs at the onset of upwelling when the upwelled water has high nutrients and low phytoplankton biomass. Subsequently, as solar heating stabilizes the water column, the phytoplankton grows rapidly in the presence of adequate nutrient supply. In the third and final stage, phytoplankton biomass has reached its highest concentration and nutrients have been depleted (Small \& Menzies 1981, GonzalezRodriguez et al. 1992, Pitcher et al. 1993). These stages can be related to the ratio of nitrate and chlorophyll concentrations: a pre-bloom period when $\mathrm{NO}_{3}{ }^{-}-\mathrm{N} / \mathrm{chl}$ a $\ll 1 \mu \mathrm{mol} \mu \mathrm{g}^{-1}$ a bloom-period when $\mathrm{NO}_{3}^{-}-\mathrm{N} / \mathrm{chl} \mathrm{a} \approx$ $1 \mu \mathrm{mol} \mu^{-1}$; and a post-bloom period when $\mathrm{NO}_{3}{ }^{-} \mathrm{N} /$ chl $a \ll 1 \mu \mathrm{mol} \mu \mathrm{g}^{-1}$. In 1990, all 3 stages were sampled (pre-bloom July 10, bloom August 7, post-bloom August 21 and September 5), whereas in 1991 only pre-bloom (July 9) and bloom situations (July 23 and August 20) were encountered. The highest phytoplankton growth rates were measured during the first 2 stages and are in the range of phytoplankton growth rates measured by nitrate uptake in the Oregon upwelling by Kokkinakis \& Wheeler (1987). It is likely that phytoplankton grew slowly or not at all during post-bloom periods. Thus, even though no cell divisions took place, carbon might have been fixed to meet respiratory requirements (Eppley 1981). In this case, the low or zero phytoplankton growth might not have been reflected by ${ }^{14} \mathrm{C}$ incubations, the conventional method to measure phytoplankton productivity. During the nonupwelling stages, phytoplankton growth was always lower than during the upwelling season, even though light was saturating and nutrients not limiting. Growth rates in winter covaried with the contribution of phytoplankton larger than $20 \mu \mathrm{m}$ (largely diatoms, Table 1), suggesting that the smaller sized cells had a slower intrinsic growth rate than the larger size fraction.

In the pre-bloom periods sampled in the beginning of July of both years, grazing rates were very high in 1990 but low in 1991. The ratio of total grazer to phytoplankton biomass was higher by about a factor of 4 in 1990, explaining the high grazing rate because a proportionally large herbivore population was present. Grazing rate even exceeded phytoplankton growth in this experiment. During bloom periods, grazing rates were highest $\left(0.12\right.$ to $0.56 \mathrm{~d}^{-1}$; Table 4$)$ when phytoplankton growth rates and standing stock were high as well. During the post-bloom periods, grazing rates were non-significant even though grazer biomass had reached its highest numbers. No gymnodinoid net growth was observed during postbloom periods, and in the August 21 experiment, gymnodinoids declined rapidly (Table 3 ). It is a common observation when culturing heterotrophic protists that ingestion rates decrease considerably when the grazer population reaches steady state (Goldman et al. 1989, J. Gonzalez pers. comm.). Alternatively, the nutritional value of the phytoplankton could have been inadequate to support protist growth. Thus, the variability of grazing rates measured during the upwelling season was most likely controlled by a combination of factors, including the physiological activity of the grazers and the abundance and composition of the grazer community. Landry \& Hassett (1982) found rates of herbivory that ranged from 0.07 to $0.28 \mathrm{~d}^{-1}$ in October on the Washington shelf. These rates compare well with rates measured in the non-upwelling season off Oregon (Tables 1 \& 4).

\section{Importance of different grazer groups}

We attempted to explain the variability of grazing rates found with the abundance of the different grazer groups (Table 5). We correlated all measured grazing rates (including corrected rates when applicable) with the initial biovolumes of the grazer groups (Fig. 5). The grazer biovolumes did not correlate with grazing rate in 1990. In 1991, the biovolumes of gymnodinoids and nanoflagellates correlated strongly with grazing rates. That gymnodinoid biovolume correlated strongly in 1991, but not in 1990, can be explained by a more active population of gymnodinoids sampled during 1991, exemplified by the net growth rates measured during that year. Total grazer biomass correlated with $g$ significantly only in 1991, again indicating that the

Table 5. Correlation coefficients $\left(R^{2}\right)$ of the straight-line regression of corrected grazing rate $\left(\mathrm{d}^{-1}\right)$ and initial grazer biovolume. Regression slope is significantly different from 0 ( $p \leq 0.05)$. Slope of the correlation of choreotrichs in 1990 is negative, all other correlations have a positive slope

\begin{tabular}{|lll|}
\hline & \multicolumn{2}{c|}{$\mathrm{R}^{2}$} \\
& 1990 & 1991 \\
\hline Total grazer & 0 & $0.60^{\circ}$ \\
Gymnodinoids & 0.21 & $0.74^{\circ}$ \\
Thecate dinoflagellates & 0.18 & 0.28 \\
Choreotrichs & 0.37 & 0.09 \\
Nanoflagellates & 0.03 & $0.65^{\circ}$ \\
\hline
\end{tabular}


experiments in 1991 were conducted with a physiologically more active grazer population compared to the 1990 experiments.

Herbivory by gymnodinoid heterotrophic dinoflagellates has been known since the beginning of the century (Kofoid \& Swezy 1921, Gaines \& Elbrächter 1987) and quantitative evidence on their ecological importance is increasing both from field and laboratory studies (Bjørnsen \& Kuparinen 1991, Hansen 1991. Lessard 1991, Strom 1991, Hansen 1992, Nakamura et al. 1992, Schnepf \& Elbrächter 1992). In the samples taken from our dilution experiments, numerous gymnodinoids were observed to have diatoms in their vacuoles. This observation supports the close coupling found between the abundance of large $(\geq 25 \mu \mathrm{m})$ gymnodinoids with large celled $(>20 \mu \mathrm{m})$ phytoplankton. Applying a dual-label isotope method, Neuer \& Cowles (unpubl.) found that gymnodinoids selected phototrophic over heterotrophic food sources. Furthermore, the only grazing experiment that yielded a significant rate in the winter season (January 22, 1991) was accompanied by a large biomass of gymnodinoid dinoflagellates. These observations, together with the correlation of gymnodinoid dinoflagellate biovolume with grazing rate, indicate that these cells were important herbivores in the experiments.

The strong correlation of nanoflagellates with grazing rate in the 1991 experiments can be circumstantial and not necessarily point to a cause-effect relationship. Community clearance rates of nanoflagellates on phototrophic food sources (assuming a per cell clearance rate for herbivorous nanoflagellates of $0.028 \mu \mathrm{l}$ $\mathrm{h}^{-1}$ cell $^{-1}$; Sherr et al. 1991) was found to be very small compared to the rates of the other grazer groups (applying the dual-isotope method; Lessard \& Smith 1985, Neuer 1992, Neuer \& Cowles unpubl.). Grazing activity or high phytoplankton growth rate could have stimulated bacterial growth due to excreted organic matter and regenerated nutrients causing an increase in nanoflagellate biomass.

Choreorichs have long been thought to constitute the major protistan herbivores in the marine environment (Smetacek 1981, Verity \& Villareal 1986), likely because much of the past research was focused on the readily culturable tintinnids which prefer phytoplankton in their diet (Heinbokel 1978, Verity 1985). Recently, choreotrichs have been found to successfully compete with nanoflagellates for bacteria (Fenchel \& Jonsson 1988, Sherr \& Sherr 1989, Arndt et al. 1990), feed on aplastitic flagellates preferably, or in the same proportion with autotrophic food sources (Verity 1991) and show a high growth efficiency when fed heterotrophic microflagellates (Ohman \& Snyder 1991). Our observations of single cell feeding studies, based on the dual-label isotope method (Lessard \& Swift 1985), identified several taxonomic groups of choreotrichs that selectively ingested heterotrophic over phototrophic food sources (Neuer \& Cowles unpubl.). Furthermore, in the experiment conducted on April 12 , 1990, the highest choreotrich biomass of all experiments was accompanied by a low rate of herbivory. A portion of the choreotrichs in the experimental water might have been omnivorous or carnivorous, thus explaining the lack of a correlation between choreotrich biomass and grazing rate.

If choreotrich ciliates are found to be abundant, these are usually considered to be the major herbivores, oftentimes without investigating the occurrence of heterotrophic gymnodinoids or other herbivorous flagellates. When quantifying choreotrichs, many researchers rely on Lugol's-fixed samples (e.g. Landry \& Hassett 1982, Gifford 1988, Paranjape 1990). Gymnodinoid dinoflagellates, on the other hand, have to be quantified using epifluorescence microscopy (Lessard \& Swift 1986) since many are autotrophic, and the information of the dinoflagellate nucleus by DAPI staining is often necessary to correctly classify the cells.

Marine thecate dinoflagellates feed with a pallium, an extension of their protoplast with which they envelope diatom chains (Gaines \& Taylor 1984, Jacobson \& Anderson 1986). But the captured food is not strictly autotrophic since detrital particles as well as bacteria and flagellates can constitute food for these cells (Lessard 1985, Jacobson \& Anderson 1986, authors' pers. obs.). This group, if abundant, should be important herbivores. However, their biovolume never correlated significantly with grazing rate, perhaps as a result of their lower abundance relative to other grazer groups.

\section{Abundance and biomass comparisons}

Studies that estimated grazer biomass in upwelling regions (but not under upwelling conditions) off North America mostly focused on choreotrich ciliates, especially tintinnids. Chester (1978) found a maximum of 1000 'oligotrichs' and tintinnids $\mathrm{l}^{-1}$, with the maximum occurring in the chlorophyll maximum layer off the Washington coast in July 1974. Even though his numbers may be an underestimate since he used formaldehyde (a fixative that is known to preserve ciliates poorly; Gifford cited in Landry \& Lorenzen 1989), there is a good agreement with the numbers of choreotrichs found in the Oregon upwelling region. Nitrate data indicate that no upwelling took place during his sampling period. Beers \& Stewart (1967) found numbers of ciliates (without tintinnids) in the California Current in December 1965 of only about 11 to $53 \mathrm{l}^{-1}$. and of tintinnids of maximal $10 \mathrm{I}^{-1}$ These numbers 
could be underestimates, as well, because the samples were formaldehyde fixed and were passed through a Nitex mesh which also can cause losses of ciliates (Gifford 1988). Landry \& Hassett (1982) found higher numbers ( 2740 to 27800 choreotrichs $1^{-1}$ ) using Lugol's solution as a fixative. The upper range of his abundance estimate is higher than the ciliate density observed in our study (Table 2).

We converted our biovolume data for the different groups of grazers to organic carbon and found that choreotrichs ranged from 0.07 to $9.1 \mu \mathrm{g} \mathrm{Cl}^{-1}$, gymnodinoid dinoflagellates from 0.24 to $50.6 \mathrm{\mu g} \mathrm{C} \mathrm{l}^{-1}$, and thecate dinoflagellates from 0.1 to $16 \mu \mathrm{g} \mathrm{Cl}^{-1}$. The choreotrichs compare well with the biomass found in the temperate North Atlantic by Lessard (1991); however, the upper estimate found for thecate and gymnodinoid dinoflagellates is more typical of eutrophic temperate coastal regions (Smetacek 1981, Lessard 1991). Even though methods of collection and fixation vary with each study (and at least some of the estimates did not account for fixation shrinkage), the comparisons suggest that the coastal upwelling environment off Oregon might be particularly favorable for herbivorous dinoflagellates. Thus, the importance of herbivorous dinoflagellates in the waters off Oregon indicated in this study might be due to their proportionally higher abundance compared to other oceanic regions.

Sorokin (1978) found protozoan biomass (ciliates and flagellates) to be between 19.8 and $46.2 \mu \mathrm{g} \mathrm{Cl}^{-1}$ in the Peruvian upwelling region. The values are well within the range of values found for total heterotrophic biomass in the Oregon upwelling region ranging from 3.1 to $61 \mathrm{\mu g} \mathrm{Cl}^{-1}$ overall. Heterotrophic dinoflagellates were also found to be an abundant component of microzooplankton assemblages during the North Atlantic spring bloom experiment (Verity et al. 1993a), ranging from 0.1 to $18.3 \mu \mathrm{g} \mathrm{Cl}^{-1}$, which also lies within the range of gymnodinoid biomass found in this study.

\section{Role of protist herbivory}

The importance of protist herbivores in the upwelling region is best quantified by investigating their impact on the primary production of that region. Using the values for initial chlorophyll, $g$ and $\mu$ determined in this study, along with the equations given in Gifford (1988), potential production and the primary production grazed (when significant) were calculated and compared for the non-upwelling and the upwelling seasons (Table 6). For the non-upwelling period, potential primary production ranged from 0 to $135 \mathrm{\mu g}$ $\mathrm{C}^{-1} \mathrm{~d}^{-1}$. Grazing impact was statistically significant only in January 1991 and measured $82 \%$ of the potential production. As pointed out before, the low grazing
Table 6. Summary of grazing impact on potential primary production during the non-upwelling and upwelling season in units of carbon. NS: grazing rate was not significantly different from zero; ND: could not be determined

\begin{tabular}{|c|c|c|c|}
\hline Date & $\begin{array}{c}\text { Potential } \\
\text { production } \\
\left(\mu \mathrm{C} \mathrm{C}^{-1} \mathrm{~d}^{-1}\right)\end{array}$ & $\begin{array}{c}\text { Production } \\
\text { grazed } \\
\left(\mu g \mathrm{Cl}^{-1} \mathrm{~d}^{-1}\right)\end{array}$ & $\begin{array}{c}\text { Fraction } \\
\text { grazed }\end{array}$ \\
\hline \multicolumn{4}{|c|}{ Non-upwelling } \\
\hline \multicolumn{4}{|l|}{1990} \\
\hline April 12 & 119 & NS & ND \\
\hline December 13 & 14 & NS & ND \\
\hline \multicolumn{4}{|l|}{1991} \\
\hline January 22 & 75 & 61 & 0.82 \\
\hline February 25 & 36 & NS & ND \\
\hline April 13 & 135 & NS & ND \\
\hline October 11 & 0 & NS & ND \\
\hline \multicolumn{4}{|c|}{ Upwelling } \\
\hline \multicolumn{4}{|l|}{1990} \\
\hline May 8 & 0 & NS & ND \\
\hline July 10 & 64 & 77 & 1.21 \\
\hline August 7 & 3382 & 1762 & 0.52 \\
\hline August 21 & 0 & NS & ND \\
\hline September 5 & 42 & NS & ND \\
\hline \multicolumn{4}{|l|}{1991} \\
\hline May 16 & 605 & 102 & 0.17 \\
\hline July 9 & 402 & 62 & 0.16 \\
\hline July 23 & 4062 & 727 & 0.18 \\
\hline August 20 & 1579 & 612 & 0.39 \\
\hline
\end{tabular}

rates measured during the other experiments conducted in winter and spring were probably trustworthy without yielding a significant result. In these experiments, the production grazed ranged from 2 to $48 \mu \mathrm{g} \mathrm{C}$ $1^{-1} \mathrm{~d}^{-1}$, or 6 to $40 \%$ of potential production (data based on untreated replicate dilution series, not shown in Table 6). During the upwelling period, primary production ranged from 0 to $4257 \mathrm{gg} \mathrm{C}^{-1} \mathrm{~d}^{-1}$. A variable proportion was grazed ( 0 to $121 \%$ ). The highest proportion of potential primary production grazed (121\%) was found during the prebloom-period sampled July 10,1990 , but in terms of carbon units this date was comparable to the non-upwelling period because of the low phytoplankton standing stock. Similarly, during the post-bloom period primary production was low due to low growth rates and biomass (September 5, 1991, Tables $1 \& 6$ ) or because no phytoplankton growth could be measured (August 21, 1990, Table 6). During the bloom-periods, however, potential primary production reached its highest values and grazing impact varied within a relatively narrow range, from 18 to $52 \%$. Thus, microzooplankton grazing has its greatest impact during bloom periods because of the high phytoplankton biomass, growth and grazing rates.

In coastal waters off Washington in October 1980 , Landry \& Hassett (1982) found microzooplankton to 
graze 17 to $52 \%$ of the daily primary production, based upon results of dilution experiments. This is well within the range of the grazing impact found in this study. Applying feeding and growth rates of ciliates determined in the laboratory to abundances in the field, ciliates were estimated to graze from 5 to $24 \%$ in the upwelling off the coast of Peru in June 1969 (Beers et al. 1971), and from 7 to $52 \%$ in the California Current during summer 1967 (Beers \& Stewart 1970). Even though these figures are indirect estimates which do not include grazing by dinoflagellates and are based on the assumption that all ciliates are herbivorous, the upper limit of the data are comparable with our findings for the bloom period in the upwelling season $(26$ to $50 \%$, Table 6). Landry \& Lorenzen (1989) estimated a lower grazing impact of ciliates with 6 to $7 \%$ in nearshore waters off Washington in August 1981. Mesozooplankton grazing, in comparison, was between 15 and $40 \%$ of primary production in nearshore waters off Washington in August 1981 (Landry \& Lorenzen 1989). In the Peru upwelling system in April 1977, mesozooplankton harvested less than $5 \%$ of the daily primary production (Dagg et al. 1980). Hansen (1992) argued that large heterotrophic dinoflagellates likely compete with copepods for diatom prey, but because of their much shorter generation times are able to respond quickly to changes in prey abundance. Microzooplankton grazing measured in other coastal regions off the east coast of North America is similar in range to what was found in this study (see Gifford 1988). However, in terms of carbon units, potential production and production grazed are larger by several orders of magnitude during the bloom period in the upwelling region.

This study shows that the microbial food web is an important component of the trophic interactions in a high productivity upwelling region. The abundance of gymnodinoid dinoflagellates, their ability to ingest diatom prey and the close link found between their abundance and herbivory gives this group a key position among the microzooplankton grazers in this region.

Acknowledgements. We are deeply indepted to L. Fessenden and M.-L. Dickson for their kind collaboration in the field and laboratory. M.-L. Dickson also provided the nitrate data. We also thank the captains of RV 'Sacajawea' for their help. E. Sherr, S. Gregory and F. Garcia-Pichel made comments on earlier versions of the manuscript. This work was supported by NSF-grant OCE-8620174 to T.J.C., J. Moum and P. Wheeler

\section{LITERATURE CITED}

Arndt, H., Jost, G., Wasmund, N. (1990). Dynamics of pelagic ciliates in eutrophic estuarine waters: importance of func- tional groups among ciliates and responses to bacterial and phytoplankton production. Arch. Hydrobiol. Beih. 34: 239-245

Azam, F., Fenchel, T., Field, J. G., Grey, J. S., Meyer-Reil, L. A., Thingstad, F. (1983). The ecological role of water-column microbes in the sea. Mar. Ecol. Prog. Ser. 10: 252-263

Bakun, A. (1973). Coastal upwelling indices, west coasts of North America, 1946-71. NOAA Tech. Rep. NMFS SSRF671

Barber, R. T., Smith, R. L. (1981). Coastal upwelling ecosystems. In: Longhurst, A. R. (ed.) Analysis of marine ecosystems. Academic Press, London, p. 31-67

Beers, J. R., Reid, F. M. H., Stewart, G. L. (1980). Microplankton population structure in southern California nearshore waters in late spring. Mar. Biol, 60: 209-226

Beers, J. R., Stevenson, M. R., Eppley, R. W., Brooks, E. L. (1971). Plankton populations and upwelling off the coast of Peru, June 1969. Fish. Bull. U.S. 69: 859-876

Beers, J. R., Stewart, G. L. (1967). Micro-zooplankton in the euphotic zone at five locations across the California current. J. Fish. Res. Bd Can. 24: 2053-2068

Beers, J. R., Stewart, G. L. (1970). The ecology of the plankton off La Jolla, California in the period April-Sept., 1967. Part VI. Numerical abundance and estimated biomass of microzooplankton. Bull. Scripps Inst. Oceanogr. 17: 67-87

Bjørnsen, P. K., Kuparinen, J. (1991). Growth and herbivory by heterotrophic dinoflagellates in the Southern Ocean, studied by microcosm experiments. Mar. Biol. 109: 397-405

Booth, B. C. (1987). The use of autofluorescence for analyzing oceanic phytoplankton communities. Botanica mar. 30: $101-108$

Burkill, P. H., Edwards, E. S., John, A. W. G., Sleigh, M. A. (1993). Microzooplankton and their herbivorous activity in the northeastern Atlantic Ocean. Deep Sea Res. II 40: 479-493

Burkill, P. H., Mantoura, R. F. C., Llewellyn, C. A., Owens, N. J. P. (1987). Microzooplankton grazing and selectivity of phytoplankton in coastal waters. Mar. Biol. 93: 581-590

Caron, D. A., Goldman, J. C. (1990). Protozoan nutrient regeneration. In: Capriulo, G. M. (ed.) Ecology of marine protozoa. Oxford University Press, New York, p. 283-306

Chester, A. J. (1978). Microzooplankton relative to a subsurface chlorophyll maximum layer. Mar. Sci. Comm. 4: $275-292$

Choi, J. J., Stoecker, D. K. (1989). Effects of fixation on cell volume of marine planktonic protozoa. Appl environ. Microbiol. 55: 1761-1765

Corliss, J. O. (1979). The ciliated Protozoa. Pergamon Press, Oxford

Dagg, M., Cowles, T., Whitledge, T., Smith, S., Howe, S., Judkins, D. (1980). Grazing and excretion by zooplankton in the Peru upwelling system during April 1977. Deep Sea Res. 27: 43-59

Dodge, J. D. (1982). Marine dinoflagellates of the British Isles. Her Majesty's Stationery Office, London

Dodge, J. D., Toriumi, S. (1993). A taxonomic revision of the Diplopsalis group (Dinophyceae). Botanica mar 36: $137-147$

Ducklow, H. W. (1983). Production and fate of bacteria in the oceans. BioSci. 33: 494-501

Dugdale, R. C., Goering, J. J. (1967). Uptake of new and regenerated froms of nitrogen and primary productivity. Limnol. Oceanogr. 12: 196-206

Edler, L. (ed.) (1979). Recommendations on methods for marine biological studies in the Baltic Sea. Phytoplankton and chlorophyll. The Baltic Marine Biologists, Malmö

Elbrächter, M. (1991). Faeces production by dinoflagellates 
and other small flagellates. Mar. microb. Food Webs 5: 189-204

Elbrächter, M., Drebes, G. (1978). Life cycles, phylogeny and taxonomy of Dissodinium and Pyrocystis (Dinophyta). Helgoländer wiss. Meeresunters. 31: 347-366

Eppley, R. W. (1981). Relations between nutrient assimilation and growth in phytoplankton with a brief review of estimates of growth rate in the ocean. In: Platt, T. (ed.) Physiological bases of phytoplankton ecology. Can. Bull. Fish. Aquat. Sci. 219: 346, 251-263

Eppley, R. W., Peterson, B. J. (1979). Particulate organic matter flux and planktonic new production in the deep ocean. Nature 282: 677-680

Fanning, K. A., Carder, K. L., Betzer, P. R. (1982). Sediments resuspension by coastal waters: a potential mechanism for nutrient recycling on the ocean's margins. Deep Sea Res. 29: 953-965

Fenchel, T., Jonsson, P. R. (1988). The functional biology of Strombidium sulcatum, a marine oligotrich ciliate (Ciliophora, Oligotrichina). Mar. Ecol. Prog. Ser. 48: 1-15

Fessenden, L., Cowles, T. J. (1994). Copepod predation on phagotrophic ciliates in Oregon coastal waters. Mar. Ecol. Prog. Ser. 107: 103-111

Gaines, G., Elbrächter, M. (1987). Heterotrophic nutrition. In: Taylor, F. J. R. (ed.) The biology of the dinoflagellates. Blackwell Scientific, Oxford, p. 224-268

Gaines, G., Taylor, F. J. R. (1984). Extracellular digestion in marine dinoflegellates. J. Plankton Res. 6: 1057-1061

Gallegos, C. L. (1989). Microzooplankton grazing on phytoplankton in the Rhode River, Maryland: nonlinear feeding kinetics. Mar. Ecol. Prog. Ser. 57: 23-33

Garrison, D. L. (1991). An overview of the abundance and role of protozooplankton in Antarctic waters. J. Mar. Sys. 2: $317-331$

Gifford, D. J. (1988). Impact of grazing by microzooplankton in the northwest arm of Halifax Harbour, Nova Scotia. Mar. Ecol. Prog. Ser. 47: 249-258

Goldman, J. C., Dennett, M. R., Gordin, H. (1989). Dynamics of herbivorous grazing by the heterotrophic dinoflagellate Oxyrrhis marina. J. Plankton Res. 11: 391-407

Gonzalez-Rodriguez, E., Valentin, J. L., André, D. A., Jacob, S. A. (1992). Upwelling and downwelling at Cabo Frio (Brazil): comparison of biomass and primary production responses. J. Plankton Res. 14: 289-306

Hansen, P. J. (1991). Quantitative importance and trophic role of heterotrophic dinoflagellates in a coastal pelagial foodweb. Mar. Ecol. Prog. Ser. 73: 253-261

Hansen, P. J. (1992). Prey size selection, feeding rates and growth dynamics of heterotrophic dinoflagellates with special emphasis on Gyrodinium spirale. Mar. Biol. 114: $327-334$

Heinbockel, J. F. (1978). Studies on the functional role of tintinnids in the Southern California Bight. II. Grazing rates of field populations. Mar. Biol. 47: 191-197

Huyer, A. (1976). A comparison of upwelling events in two locations: Oregon and Northwest Africa. J. mar. Res. 34: $531-546$

Huyer, A. (1983). Coastal upwelling in the California Current system. Prog. Oceanogr. 12: 259-284

Jacobson, D. M., Anderson, D. M. (1986). Thecate heterotrophic dinoflagellates: feeding behavior and mechanisms. J. Phycol. 22: 249-258

Jerome, C. A. , Montagnes, D. J. S., Taylor, F. J. R. (1993). The effect of the quantitative protargol stain and Lugol's and Bouin's fixatives on cell size: a more accurate estimate of ciliate species biomass. J. eukaryot. Microbiol. 40: $254-259$
Juhl, A. R. (1991). The biology of a shallow water vent. M.Sc. thesis, Oregon State University, Corvallis

Kimor, B. (1981). Seasonal and bathynetric distribution of thecate and nonthecate dinoflagellates off la Jolla, California. Calif. coop. oceanic Fish. Invest. Rep. 22

Kleinbaum, D. G., Kupper, L. L. (1978). Applied regression analysis and other multivariable methods. Wadsworth Publishing Company, Inc., Belmont, CA

Kofoid, C. A., Swezy, O. (1921). The free-living unarmored Dinoflagellata. University of California Press, Berkeley

Kokkinakis, S. A., Wheeler, P. A. (1987). Nitrogen uptake and phytoplankton growth in coastal upwelling regions. Limnol. Oceanogr. 32: 1112-1123

Landry, M. R. (1993). Estimating rates of growth and grazing mortality of phytoplankton by the dilution methods. In: Kemp, P., Cole, J., Sherr, B., Sherr, E. (eds.) Current methods in aquatic microbial ecology. Lewis Publishers, New York, p. 715-722

Landry, M. R., Haas, L. W., Fagerness, V. L. (1984). Dynamics of microbial plankton communities: experiments in Kaneohe Bay, Hawaii. Mar. Ecol. Prog. Ser. 16: 127-133

Landry, M. R., Hassett, R. P. (1982). Estimating the grazing impact of marine micro-zooplankton. Mar. Biol. 67: $283-288$

Landry, M. R., Lorenzen, C. J. (1989). Abundance, distribution and grazing impact of zooplankton on the Washington shelf. In: Landry, M. R., Hickey, B. M. (eds.) Coastal oceanography of Washington and Oregon. Elsevier, Amsterdam, p. 175-210

Lessard, E. J. (1991). The trophic role of heterotrophic dinoflagellates in diverse marine environments. Mar. Microb. Food Webs 5: 49-58

Lessard, E. J., Swift, E. (1985). Species-specific grazing rates of heterotrophic dinoflagellates in oceanic waters, measured with a dual-label isotope technique. Mar. Biol. 87: $289-296$

Lessard, E. J., Swift, E. (1986). Dinoflagellates from the North Atlantic classified as phototrophic or heterotrophic by epifluorescence microscopy. J. Plankton Res. 8: $1209-1215$

Lund, J. W. G., Kipling, C., Cren, E. D. L. (1958). The inverted microscope method of estimating algal numbers and the statistical basis of estimations by counting. Hydrobiologia 11: $143-170$

Michaels, A. F., Silver, M. W. (1988). Primary production, sinking fluxes and the microbial food web. Deep Sea Res. 35: $473-490$

Montagnes, D. J. S., Lynn, D. H. (1991). Taxonomy of choreotrichs, the major marine planktonic ciliates, with emphasis on the aloricate forms. Mar. microb. Food Webs 5: $59-74$

Nakamura, Y., Yamazaki, Y., Hiromi, J. (1992). Growth and grazing of a heterotrophic dinoflagellate, Gyrodinium dominans, feeding on a red tide flagellate, Chattonella antiqua. Mar. Ecol. Prog. Ser. 82: 275-279

Neuer, S. (1992). Role of protist grazing in the Oregon Upwelling System. Ph.D. thesis, Oregon State University, Corvallis

Neuer, S., Franks, P. J. S. (1993). Determination of ammonium uptake and regeneration using the seawater dilution method. Mar. Biol. 116: 497-505

Ohman, M. D., Snyder, R. A. (1991). Growth kinetics of the omnivorous oligotrich ciliate Strombidium sp. Limnol. Oceanogr. 36: 922-935

Paranjape, M. A. (1990). Microzooplankton herbivory on the Grand Bank (Newfoundland, Canada): a seasonal study. Mar. Biol. 107: 321-328 
Pitcher, G. C., Bolton, J. J., Brown, P. C., Hutchings, L. (1993) The development of phytoplankton bloooms in upwelled waters in the southern Benguela upwelling systemas determined by microcosm experiments. J. exp. mar. Biol. Ecol. 165: 171-189

Porter, K. G., Feig, Y. S. (1980). The use of DAPI for identifying and counting aquatic microflora. Limnol. Oceanogr. 25: $943-948$

Price, N. M., Andersen, L. F., Morel, F. M. M. (1991). Iron and nitrogen nutrition of equatorial Pacific plankton. Deep Sea Res. 38: 1361-1378

Ryther, J. H. (1969). Photosyntheis and fish production in the sea. Science 166: 72-76

Sanders, R. W., Porter, K. G. (1988). Phagotrophic phytoflagellates. In: Marshall, K. C. (ed.) Advances in microbial ecology. Plenum Press, New York, p. 167-192

Schnepf, E., Elbrächter, M. (1992). Nutritional strategies in dinoflagellates. A review with emphasis on cell biological aspects. Eur. J. Protistol. 28: 3-24

Shapiro, L. P., Haugen, E. M., Carpenter, E. J. (1989). Occurrence and abundance of green-fluorescing dinoflagellates in surface waters of the Northwest Atlantic and Northeast Pacific oceans. J. Phycol. 25: 189-191

Sherr, B., Sherr, E. (1989). Trophic impacts of phagotrophic protozoa in pelagic foodwebs. In: Hattori, T, Ishida, Y.. Maruyama, Y., Morita, R. Y., Uchida, A. (eds.) Recent advances in microbial ecology. Japan Scientific Societies Press, Tokyo, p. 388-393

Sherr, B. F., Sherr, E. B. (1991). Proportional distribution of total numbers, biovolume, and bacterivory among size classes of 2-20 um nonpigmented marine flagellates. Mar. microb. Food Webs 5: 227-237

Sherr, E. B., Sherr, B. F. (1988). Role of microbes in pelagic food webs: a revised concept. Limnol. Oceanogr. 33: $1225-1227$

Sherr, E. B., Sherr, B. F., McDaniel, J. (1991). Clearance rates of $6 \mu \mathrm{m}$ fluorescently labeled algae (FLA) by estuarine protozoa: potential grazing impact of flagellates and ciliates. Mar. Ecol. Prog. Ser. 69: 81-92

Small, L. F., Menzies, D. W. (1981). Patterns of primary productivity and biomass in a coastal upwelling region. Deep Sea Res. 28: 123-149

Small, L. F. Ramberg, D. A. (1971). Chlorophyll a, carbon, and nitrogen in particles from a unique coastal environment. In: Costlow, J D. (eds.) Fertility of the sea. Gordon and Breach, p. $475-492$

Smetacek, V. (1981). The annual cycle of protozooplankton in the Kiel Bight. Mar. Biol. 63: 1-11

Smith, R. L. (1968). Upwelling. Oceanogr. mar. Biol. A. Rev. 6: $11-46$

Smith, W. O., Barber, R. T (1979). A carbon budget for the autotrophic ciliate Mesodinium rubrum. J. Phycol. 15: $27-33$

This article was presented by B. \& E. Sherr (Senior Editorial Advisors), Corvallis, Oregon, USA
Sorokin, Y I. (1978). Description of primary production and of the heterotrophic microplankton in the Peruvian upwelling region. Oceanology 18: 62-71

Stoecker, D. K. (1984). Particle production by planktonic ciliates. Limnol. Oceanogr. 29: 930-940

Stoecker, D. K., Capuzzo, J. M. (1990). Predation on protozoa: its importance to zooplankton. J. Plankton Res. 12: $891-908$

Stoecker, D. K., Silver, M. W., Michaels, A. E., Davis, L. H. (1988). Obligate mixotrophy in Laboea strobila, a ciliate which retains chloroplasts. Mar. Biol. 99: 415-423

Strathmann, R. R. (1967). Estimating the organic carbon content of phytoplankton from cell volume or plasma volume. Limnol. Oceanogr. 12: 411-418

Strom, S. (1991). Grazing and growth rates of the herbivorous dinoflagellate Gymnodinium sp. from the subarctic Pacific Ocean. Mar. Ecol. Prog. Ser. 78: 103-113

Throndsen, J. (1978). Preservation and storage. In: Sournia, A. (ed.) Phytoplankton manual. UNESCO, Paris, p. 69-74

Venrick, E. L. (1978). Statistical considerations, In: Sournia, A. (ed.) Phytoplankton manual. UNESCO, Paris, p. 238-250

Verity, P. G. (1985). Grazing, respiration, excretion, and growth rates of tintinnids. Limnol. Oceanogr. 30: $1268-1282$

Verity, P. G. (1991). Measurement and simulation of prey uptake by marine planktonic ciliates fed plastidic and aplastidic nanoplankton. Limnol. Oceanogr. 36: 729-750

Verity, P. G., Stoecker, D. K., Sieracki, M. E., Burkill, P. H., Edwards, E. S., Tronzo, C. R. (1993a). Abundance, biomass and distribution of heterotrophic dinoflagellates during the North Atlantic spring bloom. Deep Sea Res. II 40: $227-244$

Verity, P. G., Stoecker, D. K., Sieracki, M. E., Nelson, J. R. (1993b). Grazing, growth and mortality of microzooplankton during the 1989 North Atlantic spring bloom at $47^{\circ} \mathrm{N}$, $18^{\circ} \mathrm{W}$. Deep Sea Res. I 40: 1793-1814

Verity, P. G., Villareal, T. A. (1986). The relative food value of diatoms, dinoflagellates, flagellates and cyanobacteria for tintinnid ciliates. Arch. Protistenkd. 131: 71-84

Wailes, G. H. (1943). 1. Protozoa. 1f. Ciliata. The University of Toronto Press for the Fish. Res. Bd Can., Toronto

Walsh, J. J., Rowe, G. T., Iversor, R. L., McRoy, C. P. (1981). Biological export of shelf carbon is a sink of the global $\mathrm{CO}_{2}$ cycle. Nature 291. 196-201

Welshmeyer, N. A., Lorenzen, C. A. (1985). Pigment budgets: zooplankton grazing and growth in a temperate fjord and the Central Pacific Gyre. Limnol. Oceanogr. 30: 1-21

Wheeler, P. A., Kirchman, D. A. (1986). Utilization of organic and inorganic forms of nitrogen by bacteria in marine systems. Limnol. Oceanogr. 31: 998-1009

Wheeler, P. A., Kokkinakis, S. A. (1990). Ammonium recycling limits nitrate use in the oceanic subarctic Pacific. Limnol. Oceanogr. 35: 1267-1278

Manuscript first received: December 10, 1992

Revised version accepted: May 31, 1994 